\title{
Pentagon Fraud Analysis in Detecting Fraudulent Financial Statements in Pharmaceutical Companies Listed on the Indonesia Stock Exchange (IDX)
}

\author{
Masnawaty Sangkala ${ }^{1, *}$, Nurhidaya Safitri ${ }^{2}$ \\ ${ }^{1}$ Department of Accounting, Universitas Negeri Makassar, Makassar, Indonesia \\ ${ }^{2}$ Department of Accounting, Universitas Negeri Makassar, Makassar, Indonesia \\ *Corresponding author.Email: Masnawaty.s@unm.ac.id
}

\begin{abstract}
This study aims: to obtain evidence regarding the existence of partial and simultaneous effect of the component fraud pentagon on the possibility of fraudulent financial statements in pharmaceutical companies listed on the Indonesia Stock Exchange. The variables in this study are: (1) financial statement fraud as the dependent variable (Y) which is measured using the F-Score, and (2) the component fraud pentagon consisting of pressure, opportunity, rationalization, capability, and arrogance as variables $(\mathrm{X})$ which is measured using the formula leverage and variables dummy. The population in this study is the annual report of pharmaceutical companies listed on the Indonesia Stock Exchange, while the samples in this study were 7 pharmaceutical companies listed on the Indonesia Stock Exchange which were taken using purposive sampling technique. Data collection is done by using documentation technique. The processed data is secondary data. Data analysis was carried out using the Classical Assumption Test, Multiple Linear Regression Analysis and Hypothesis Testing. The results showed Y $=-5,218+(3.325) \mathrm{LEV}+(-3,267)$ BDOUT + $(1,197) \mathrm{KAP}$ BIG4 + $(0,557)$ DCHANGE + $(0,388)$ CEOPIC + e. Based on the results of the analysis, it can be seen that pressure (external pressure), opportunity (ineffective supervision), rationalization (quality of external auditors), and capability (change of directors) partially have no effect on financial statement fraud. Meanwhile, arrogance (number of photos of the CEO displayed) partially has a positive effect on financial statement fraud. CEO displayed) simultaneously has a positive effect on fraudulent financial statements.
\end{abstract}

Keywords: Pentagon Fraud, Financial Report Fraud

\section{INTRODUCTION}

The existence of information related to the company's financial position, financial performance, and the existence of cash flows commonly used by management and investors in making economic decisions is referred to as financial statements [1]. Investors, and potential investors, creditors and potential creditors, the public government, and labor or labor unions. With the use of resources in the company that has been provided, accountability must be made as a form of management of expenses or usage, then a financial report is made. So every company tries to present financial reports with good performance. This triggers fraud or manipulation of financial statements in a company [2].
The problem of fraud is a problem that is growing at this time. The perpetrators who commit fraud are currently not only limited to the upper class, but many have touched the lower layers of employees. This is certainly one thing that needs to be watched out for because it is detrimental to other parties [3] [4]. The form of fraud committed by the company is manipulating financial statements, which is better known as fraudulent financial reporting. The preparation of reports on company finances that are prepared intentionally with the intention of manipulating financial amounts that have been used are called fraudulent financial statements [5].

Based on research results from ACFE (Association of Certified Axaminers), it was found that $77 \%$ came from corruption, 19\% from asset abuse, and as much as $4 \%$ due to financial statement fraud [6]. Despite having 
a small percentage, fraudulent financial statements resulted in very large losses of more than 10 billion rupiah. An example of a case in a pharmaceutical company, namely PT Kimia Farma Tbk, which committed fraud by manipulating a net profit of Rp. 132 billion in its 2001 financial statements, then restated it and found a fairly basic error, overstating namely sales and inventories [7] [8].

Misstatements related to inventory marked up by the production director and the audit firm that conducted the audit failed to detect the fraud [9] [10]. Another case in the pharmaceutical sector is PT. In 2001, Indofarma manipulated the financial statements by doing a markup on drug inventories of Rp. 28.87 billion as a result, the cost of goods sold was understated and profit was overstated by the same value [11]. While the latest case comes from PT. Merck Tbk (MERK) was sanctioned by the IDX for the revision of the dividend value to be distributed to shareholders from Rp 3,260/share to Rp $2,565 /$ share in the financial statements in November 2018. Whereas the previous dividend ratio has increased MERK's shares by $38.89 \%$ [12].

Along with the number ofcases fraud, auditors need to detect as early as possible the potential for fraud by considering several perspectives, one of the theories that discusses fraud is the theory Fraud Pentagon developed by Crowe which consists of 5 elements later became known as the Pentagon Fraud [13] [14] [15]. The elements in the fraud pentagon cannot be studied just like that, therefore the measurement of variables is based on the availability of data in the company's annual report related to the variables to be studied. Thus, pressure is measured by external pressure, opportunity is measured by the ineffectiveness of the commissioner's supervision, rationalization is measured by the quality of external auditors, capability is measured by the change of directors, and arrogance is measured by the number of CEO photos displayed in the company's annual report [16].

The use of pentagon theory in this study aims to detect fraud [17]. The Fraud variable uses the F-Score analysis method in order to see that fraud that occurs in the company's financial statements can be influenced by arrogance, capability, pressure, and existing opportunities [18].

Based on the background that has been put forward by the reviewer, this study aims to analyze fraud in financial statements, especially in companies that have been listed on the Indonesia Stock Exchange (IDX).In this study, the authors examine the pharmaceutical sector regarding the potential for fraud using themodel fraud latest, namely the Pentagon Fraud.

\section{LITERATURE REVIEW}

\subsection{Fraud (Fraud)}

\subsubsection{Definition of Fraud (Fraud)}

Fraud is a presentation of financial statements that is intentionally mistaken (contains misstatements) [19].

Meanwhile, according to SAS99No." Through audit activities, it is found that activities that result in incorrect recordings in the company's financial statements are referred to as fraud or fraud."[20].

\subsubsection{Types of Fraud}

According to Hery there are 2 types of fraud consisting of [21]:

\section{1) Misappropriation of Assets}

The existence of fraud in the form of theft of company assets in the form of fraud is referred to as misappropriation of company assets [22]. These thefts are generally carried out by employees in relatively small and immaterial amounts. The embezzlement of assets is also carried out by top management in a significant amount considering the position of top management which has greater authority and control over the company's assets.assets is usually carried out in the following ways [23]:

a. Cash receipts and collection of accounts receivable from customers

b. Misappropriation of Misappropriating the company's Stealing company assets for personal use or selling

c. Accepting bribes from suppliers

d. Using company assets as collateral to creditors for personal loans

e. Taking company cash in the form of discounts purchases obtained from suppliers

f. Taking company cash through fictitious supplier payments

2) Misleading Misleading

According to Tuanakotta the typology of fraud is as follows [24]:

\section{a. Corruption}

Cases of this type of fraud often occur in developing countries, as a result of weak law enforcement and integrity factors. Fraud Thisis difficult to detect because of the cooperation of the parties who need each other [25]. 


\section{b. Fraudulent Statement Financial statement}

Through audit activities, it is found that activities that result in incorrect recordings in the company's financial statements are referred to as fraud or fraud [26]. This fraud that occurs is a form of fraud that is physical and easy to measure so that it can be detected easily and this is a type of fraud.

\section{c. Asset Misappropriation}

This fraud that occurs is a form of fraud that is physical and easy to measure so that it can be detected easily and this is a type of fraud. The theft of assets that occurs is an act of fraud or misappropriation of assets in the company [27].

\subsection{Financial Statement Fraud Financial Statement}

\subsubsection{Definition of Fraud Financial}

According to Alvin A. Arens, one of the things that is intentional by eliminating or manipulating the results of the amount with the intent to manipulate the financial statements is a fraud that often occurs in companies [28]. Based on the opinion of Sihombing in [29], he argues that someone intentionally commits fraud on the incompatibility of financial statements with the principles that exist in accounting theory that has been used so far is a form of fraud in financial statements. [7]. According to ACFE, Financial statement fraud is a scheme that intentionally causes misstatements or intentionally does not include material information in financial statements [19].

\subsubsection{The Purpose of Fraudulent Financial Statements}

According to Hurlock the purpose of fraudulent financial statements, namely [30]:

1) Increase the value of wealth to gain profits through the sale of shares because the value increases

2) To get a more profitable source of financing related to bank credit or other financial institutions.

3) To describe better profit gain

4) To cover the inability to make money

5) To eliminate the negative perception of the market

6) To get awards/bonuses

\subsubsection{Fraud Pentagon}

Theory Triangle which was first coined by Dr.Donal Cressey, one of the founders of ACFE regarding behavior is fraudulent supported by 3 elements, namely pressure, opportunity, and rationalization. Development of the previous theory discovered by Wolf and Hermanson as Fraud Diamond. This adds a new element oftheory, Triangle namely the element of capability or capability. According to Wolfe, many frauds, especially billions of dollars in value, are impossible without certain competencies or capabilities within the company [13]. Someone who has the capability to recognize opportunities and take advantages that are lived regularly.

The latest discovery to refine the previous theory, namely the Pentagon Fraud, was put forward by Crowe [5], which is an extension of the fraud triangle and fraud diamond theory. In this theory, it adds a new element, namely arrogance. This arrogance arises from the belief that he is able to deceive and go undetected without fear of being found out. The following is a description of the fraud pentagon:

\section{1) Pressure}

Pressure is a condition where management or other employees feel the urge or pressure to materially misrepresent financial statements [31]. Pressure can also be caused by financial and non-financial factors. Financial factors arise due to economic demands, while non-financial factors arise due to actions to cover up poor performance [32]. Forms of pressure that lead to fraud, such as financial stability or profitability where companies are threatened by economic conditions and other industries such as decreased requirements and other loan terms and personal assets of the board of directors that are materially threatened by the entity's financial performance that triggers fraudulent financial statements.

\section{2) Opportunity}

Opportunity is a situation that opens an opportunity for management or employees to misuse financial statements. Opportunity is a condition where the company environment provides opportunities for management and employees to make financial statements that contain misstatements [14]. Companies that have weak internal controls will have many loopholes that create opportunities for management to manipulate transactions [15]. The ineffectiveness of staff in the accounting, internal audit, and information processing departments as well including the audit committee or executive which is also known as the board of commissioners in carrying out their supervisory function of the financial reporting process can also create opportunities for misstatements to occur. Another condition that becomes an opportunity for fraud to occur is a condition where the company involves a lot of accounting considerations and estimates that are difficult to verify. There are 3 conditions that trigger it, namely subjective accounting estimates, ineffectiveness of the board of directors, weak internal control by the audit committee. 


\section{3) Rationalization}

Someone who cheats by not acting honestly because they are in a depressed position is in an environment that makes them uncomfortable so that they commit fraud then they do not have irrational attitudes, character, and ethical values.. Rationalization refers to the perpetrator's thinking of justifications and reasons that immoral behavior is different from criminal acts. Rationalization is a behavior or character that causes management and employees to act dishonestly or an environment that makes them act dishonestly and justifies the dishonest act.

4) Capabilities

Capability is the ability of a person to commit fraud based on the expertise and position occupied in the company. According to Wolfe \& Hermanson, individuals who have the potential to commit fraud [13]. The attitudes related to capabilities are position/function, intelligence and creativity, confidence, skill in influencing, and good at lying [16]. The form of capability can be measured by the directors is by recruiting new competent directors. The existence of a change of directors can also indicate political interests, and management performance due to adjustments [32].

\section{5) Arrogance}

According to [33] Someone who is arrogant or arrogant can be able to commit fraud or deception. They have a high-minded nature and always think that they have the right or the advantage to control company policies and procedures that are not in accordance with their wishes, this is usually called someone who is arrogance., this arises due to the large amount of selfinterestin a person which raises the belief that the fraud committed will not be detected [19]. The form of arrogance can be measured by looking at describing the level of arrogance of a leader.

\section{RESEARCH METHODS}

\subsection{Variables The}

The dependent variable in this study is Financial Statement Fraud which is symbolized Y, while the independent variable consists of five factors, namely Pressure is symbolized by X1, Opportunity is symbolized by X2, Rationalization is symbolized by X3, Capability is symbolized by X4, and Arrogance is symbolized by X5.

\section{RESULTS AND DISCUSSION}

\subsection{The Effect of Pressure on Fraudulent Financial Statements}

Based on the results of the data presentation in the table. The results of multiple regression can be seen that the regression coefficient of the external pressure proxy (leverage) is 3.325 with a significance value greater than the value of Sig. 0.05 , which is 0.219 , so the results of the study can be said that financial statement fraud is not influenced by external pressure. In this study, it was found that external pressure as measured by theratio leverage cannot be a reference to see the occurrence of fraudulent financial statements in pharmaceutical companies listed on the IDX for the 2015-2019 period.

The ineffectiveness of this variable can be caused because the company has an alternative other than obtaining loan funds to increase its capital, namely by issuing shares. This can happen because in every company, funding in the form of debt from third parties has many risks, for example the company is unable to pay off existing debts. In addition, if the company can manage existing debt to increase revenue, the rate of return on capital can occur. So that management does not have to commit fraudulent financial statements to manipulate the amount of debt used to fund the company's operations.

\subsection{The Effect of Opportunity on Financial Statement Fraud}

This does not apply because the average company has complied with the Financial Services Authority Regulation Number 33/PJOK.04/2014 which requires at least $30 \%$ of the members of the board of commissioners. With the addition of the number of independent commissioners in the company with the aim of improving the company's performance with an objective assessment. However, the number of independent commissioners cannot prevent fraudulent financial statements if the independent board of commissioners is not effective in carrying out their duties. As well as the intervention of certain parties can also cause the ineffectiveness of a supervision carried out by an independent commissioner.

\subsection{Effect of Financial Statement Fraud Rationalization of the}

In the third hypothesis in this study, it can be concluded that financial statement fraud is positively and significantly influenced by the quality of the external audit.

This can happen because the ability of the resources owned by the BIG4 public accounting firm is not much different from the non-BIG4 public accounting firm in 
detecting material misstatements in the company's financial statements. Even though it comes from KAP BIG4, the auditor's ability to detect material misstatements in the client's financial statements is still lacking. So that there is no big difference in the resources of each KAP (Public Accounting Firm) because each KAP has competent resources in it. In addition, the role of auditors from KAP BIG 4 and non KAP BIG 4 has the same role in detecting fraudulent financial statements based on generally accepted accounting standards.

The results of this study are not in accordance with research conducted by Hanifa and Viva which state that the quality of external auditors has a positive effect on financial statement fraud [24],[25]. However, the results of this study are supported by research conducted by Pamungkas which states that the quality of external auditors has no effect on financial statement fraud [7].

\subsection{The Effect of Capabilities on Financial Statement Fraud}

This is because, the change of directors carried out by the company is not to cover up the fraud of the previous directors but with the aim of finding directors who are more competent than before. Substitutions are made to improve the company's performance to be better. In addition, the absence of a change of directors is caused because the board of directors and shareholders are satisfied with the performance of the board of directors so it doesn't matter if there is no change in the board of directors.

The results of this study are in line with research conducted by Pamungkas and Zelin which state that the change of directors has no effect on financial statement fraud [7] [33]. However, this study is not in accordance with the results of research conducted by Komang and Theresa which states that the change of directors has a positive effect on fraudulent financial statements [26], [34].

\subsection{Effect of Arrogance on Financial Statement Fraud}

The results of this study indicate that the number of CEO photos displayed in the company's annual financial statements has a positive coefficient. Based on table 9 . The results of multiple linear regression can be seen that the significance value is 0.00 and the coefficient value is 0.388 . Thus, it can be concluded that the number of CEO photos displayed in the company's annual financial statements has a positive and significant effect on the occurrence of fraudulent financial statements.

Based on the test results, it proves that the more photos of the CEO displayed in the company's annual financial statements can indicate a high level of CEO arrogance in the company. Which is owned. In addition, there is a possibility that a CEO will do everything he can to maintain his current position and position.

\subsection{The Effect of Pressure, Opportunity, Rationalization, Capability, and Arrogance on Fraudulent Financial Statements}

Based on the theory of Fraud pentagon which has been explained in the literature review that financial statement fraud can occur due to conditions such as pressure on management, opportunities to commit fraud and rationalization in action. In addition, capability is a supporter to commit fraud with the ability and position owned by management. As well as the attitude of superiority of someone who considers himself free from internal control (arrogance).

\section{CONCLUSION}

Based on the examination of the results of the study above, it can be concluded that: (1) fraud that occurs in the financial statements, the partial analysis is positively and significantly influenced by the organizational variable, while the fraud that occurs in the financial statements is partially not significantly affected by the variable external pressure, changes in the board of directors (capacity), as well as the ineffectiveness of variables that occur in supervision (opportunities). And (2) if viewed simultaneously, fraud that occurs in financial statements is jointly influenced by arrogance variables, external pressure variables, changes in directors (capability), and ineffectiveness variables that occur in supervision (opportunities).

\section{ACKNOWLEDGMENTS}

We thank the anonymous reviewers who have provided constructive suggestions for improving this article.

\section{REFERENCES}

[1] ACFE. (2017). Indonesian Fraud. Retrieved 11 2019, from ACFE Indonesia Chapter.

[2] Tempo.com. (2003). Business. Retrieved December 2019, from http://www.tempo.com

[3] Finance, D. (2004). Exchange and forex . Retrieved 12 2019, from http://www.detik.com

[4] CNBC Indonesia, w. M. (2018). Market News. Retrieved December 2019, from http://www.CNBCIndonesia.com

[5] Horwarth, C. (2011). The Mind Behind The Faudsters Crime: Key Behavior and Environmental Crowe Horwarth International. 
[6] Zelin, C. (2018). Pentagon Fraud Analysis in Detecting Fraud Financial Statements Using the Fraud Score Model. Yogyakarta: State University of Indonesia .

[7] Pamungkas, PA (2018). Fraud Risk Factor Analysis The theory of fraud pentagon in Detecting Fraud Financial Statements: An Empirical Study on Companies Listed in the Jakarta Islamic Index on the Indonesia Stock Exchange in 2013-2016. Yogyakarta: Islamic University of Indonesia

[8] Hery, SM (2017). Auditing and Assurance :Integrated and Comprehensive Edition. Jakarta: PT. Grasindo.

19] AICPA. (2002). Research Standards. Retrieved January 10, 2020, from the American Institute of Certified Public Accountants: https://www.aicpa.com

[10] Tuanakotta, TM (2012). Forensic Accounting and Investigative Auditing. Bogor : Salemba Four .

[11] Alvin A. Arens, RJ (2015). Auditing \& Assurance services: Integrated approach. Jakarta: publisher Erlangga.

[12] Sihombing KS, RS (2014). Pentagon Fraud Analysis in Detecting Fraud Financial Statements: An Empirical Study on Manufacturing Companies listed on the Indonesia Stock Exchange 2010-2012. Diponegoro Journal of Accounting, 2337-3806.

[13] Wolfe DT, H. (2004). The Fraud Diamond: Considering the Four Elements of Fraud. CPA Journal Vol 74 Issue 12, 38-42.

[14] Harman, SA (2019). Determinant Analysis of Fraud Financial Statements with the Perspective of Pentagon Fraud: Empirical Study on Manufacturing Companies Listed on the Stock Exchange in 2013-2017. 2019: Surabaya.

[15] Herviana, E. (2017). Fraudulent Financial Reporting: Testing the Theory of Fraud pentagon on State-Owned Enterprises (BUMN) Listed on the Indonesia Stock Exchange (IDX) for the period 2012-2016. Jakarta: Syarif Hidayatullah State Islamic University.

[16] Aulia, H. (2018). Fraud Diamond Analysis in Detecting Potential Fraud Financial Statements (Study on Manufacturing Companies listed on the IDX in 2014- 2016). Yogyakarta: Islamic University of Indonesia

[17] Baningrum, ES (2018). Detection of Fraudulent Financial Reporting using Pentagon Fraud
Analysis: A Case Study on Manufacturing Companies Listed on the Indonesia Stock Exchange 2014-2016. Indonesian Accounting and Finance Research .

[18] Marks, J. (2012). The Mind Behind The Fraudsters Crime : Key Behavior and Environmental Elements.

[19] Aprilia. (2017). Analysis of the Effect of Pentagon Fraud on Financial Statement Fraud Using the Beneish Model in Companies Implementing the Asean Corporate Governance Scorecard. Journal of Assets (Research Accounting), 101-132.

[20] Widayanto, F. (2018). Study on Financial Statement Fraud Detection with Fraud Pentagon Theory Approach at Islamic Commercial Banks registered with OJK in 2012- 2016. Yogyakarta: Sunan Kalijaga State Islamic University.

[21] Pitaloka, AP (2019), Fraud Diamond Analysis in Detecting Fraud Financial Statements, EProceeding of Management, 570-577.

[22] Ratna Dewi Agustina, DP (2019). The Effect of Pentagon Fraud in Detecting Fraudulent Financial Reporting bro. Scientific Journal of Management, Economics, and Accounting, 44-62.

[23] Muhammad Gaddafi, MT (2019). The Effect of Pentagon Fraud in Detecting Financial Statements Fraud. Seminar on Research Results of the Faculty of Economics and Business, 20-34.

[24] Hanifa, SI (2015). Effect of Fraud Indicators on Fraudulent Financial Statements: Empirical Study on Companies listed on the IDX in 2008-2013. Semarang : Diponegoro University.

[25] Viva Yustitia Rini, TA (2012). Prediction Analysis of Potential Fraudulent Financial Statement Risks through Fraud Score Model. Diponegoro Journal of Accounting, 1-15.

[26] Komang Leela Shanti Devy, MA (2017). The Influence of Frequent Number of CEO's Picture, Change of Company Directors and External Pressure in Detecting Fraudulent Financial Reporting (Empirical Study on Pharmaceutical Companies listed on the IDX for the period 20122016. E- Journal Ganesha.

[27] Theresa Ventyana Yulia Putri, JS (2019). Pentagon Fraud in Earnings Management in Metals and Chemicals Manufacturing Company. Scientific Journal of Wahana Accounting, 143-155.

[28] Bawakes, HF (2018). Testing the Pentagon's Fraud Theory on Fraudulent Financial Reporting. 
Regional Journal of Accounting and Finance, 114134.

[29] Ade Rizky Novitasari, AC (2018). Analysis of Factors Affecting Fraud Financial Statements in the Perspective of Fraud Pentagon. Diponegoro Journal of Accounting, 1-15.

[30] Zack, GM (2013). Financial Statement Fraud Strategies for Detection and Investigation. New Jersey: John Wiley \& Sons, Inc.

[31] Yusroniyah, T. (2017). Detection of Fraudulent Statements through Crowe's Fraud Pentagon Theory on State- Owned Enterprises listed on the IDX. Semarang: Semarang State University.

[32] Ghozali, I. (2013). Multivariate Analysis Application with IBM SPSS 21 Update PLS Regression Program. Semarang: Diponegoro University.

[33] Skousen CJ, TB (2009). Fraud in Emerging Markets: A Cross Country Analysis. Journal of Accounting and Auditing .

[34] Karyono. (2013). Forensic Audit. Yogyakarta: ANDI. cashmere. (2013). Financial Statement Analysis. Jakarta: PT Raja Grafindo Persada. 